\title{
Effect of Integrated Nutrient Management on Growth and Development Stages of Rice under Rice-Wheat Ecosystem
}

\author{
Shobhit Singh ${ }^{1 *}$, J.S. Bohra ${ }^{1}$, Y.V. Singh ${ }^{2}$, Amit Kumar Upadhyay ${ }^{3}$, \\ Shiv Shanker Verma ${ }^{1}$, Pankaj Kumar Mishra ${ }^{1}$ and M. Raghuveer ${ }^{1}$ \\ ${ }^{1}$ Department of Agronomy, ${ }^{2}$ Department of Soil Science and Agricultural Chemistry, Institute of \\ Agricultural Sciences, Banaras Hindu University, Varanasi, U.P., India \\ ${ }^{3}$ Department of Soil Science and Agricultural Chemistry, JNKV, Jabalpur, M.P., India \\ *Corresponding author
}

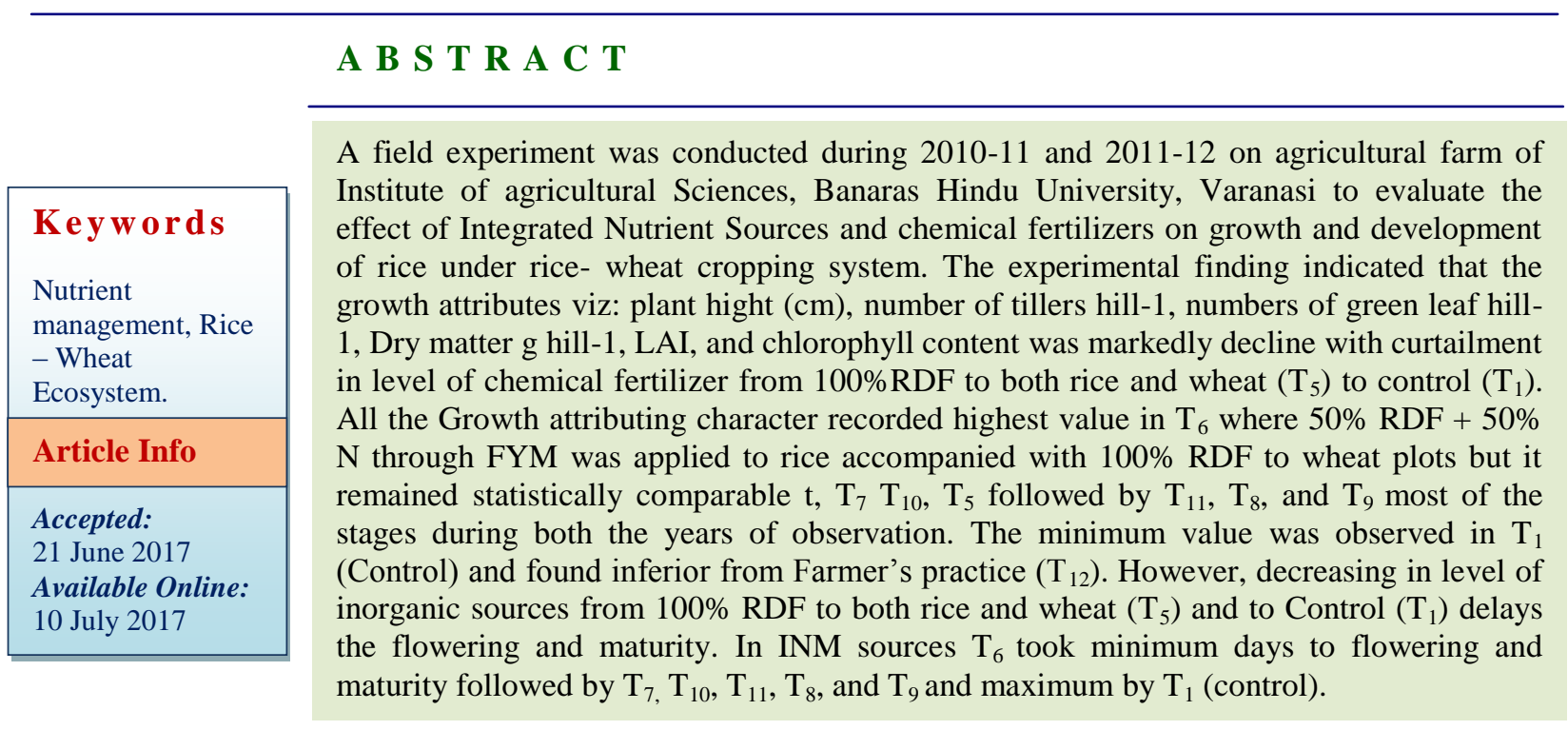

\section{Introduction}

The rice - wheat is the most dominant cropping system in Asian subtropical countries viz. China, India, Nepal, Bangladesh and Pakistan, where it is practiced in about 24 million hectares (Mahajan and Gupta, 2009).

In India too rice-wheat cropping system (RWCS) is most widely adopted system, covering over 10.5 million ha - mostly in the Indo Gangetic Plains. Among cereals, rice and wheat are the most important crops, which account for about 60 per cent of world's human energy requirement. In India, total area under rice is 43.13 million hectares and that of wheat is 29.57 million hectares with production of 100.45 and 90.38 million tonnes of respectively. However, the productivity of both rice and wheat is low i.e. 2,323 and $3056 \mathrm{~kg} / \mathrm{ha}$, respectively (GOI, 2015).

The rice-wheat production system provides staple grain for more than 400 million people. During the Green Revolution era in the 1960s, enhanced production resulted from increases 
in both rice-wheat area and system productivity. But little additional land is now available and traditional farmlands are increasingly lost to urbanization. In addition, of this rapid increasing population create huge demand in upcoming decades.

Therefore, future demand for food will have to be met mainly through increases in production per unit of harvested area (Ladha et al., 2003). The combination of poor soil fertility and inadequate, unbalanced, and inefficient use of fertilizers contributes much to this problem (Yadav et al., 2000; Dwivedi et al., 2001).

The imbalanced use of fertilizer has disturbed the natural equilibrium of the nutrient elements operating in the soils is being mostly applied for a long period. The studies have shown that the sustainability of this important system could only be achieved through integrated use of chemical and organic sources in a balanced manner.

\section{Materials and Methods}

Looking at the importance of rice - wheat system under irrigated ecosystem of Varanasi region, declining factor productivity and soil health, it is imperative to study the integrated use of chemical fertilizers and organic sources in rice- wheat system on long term basis. Therefore, with these facts in view present study conducted during 2010-11 and 2011-12. The geographical situation of the experiment lies in the Northern Gangetic Alluvial plain at $25^{\circ} 18^{\prime}$ North latitudes, $83^{\circ} 03^{\prime}$ East longitude and at an altitude of 128.93 meters above the mean sea level.

The experimental soil is sandy loam in texture with varying $\mathrm{pH} 7.72$ to 7.78 , bulk density 1.39 to $1.56 \mathrm{~g} \mathrm{cc}^{-1} 1$ as well as 146 to $221,10.5$ to 20.84 and 152 to $206 \mathrm{~kg} \mathrm{ha}^{-1} \mathrm{~N}, \mathrm{P}$, and $\mathrm{K}$, respectively. There were 12 treatments comprising 5 purely inorganic Viz. 50\% RDF to both rice and wheat $\left(\mathrm{T}_{2}\right), 50 \% \mathrm{RDF}$ to rice and $100 \%$ RDF to Wheat $\left(\mathrm{T}_{3}\right), 75 \% \mathrm{RDF}$ to both rice and wheat $\left(\mathrm{T}_{4}\right), 100 \% \mathrm{RDF}(120 \mathrm{~kg} \mathrm{~N}$ $+60 \mathrm{~kg} \mathrm{P}_{2} \mathrm{O}_{5}+60 \mathrm{~kg} \mathrm{~K}_{2} \mathrm{O} \mathrm{ha}^{-1}$ ) both rice and wheat $\left(\mathrm{T}_{5}\right)$ and farmer's practice with $(80 \mathrm{~kg} \mathrm{~N}$ $\left.+40 \mathrm{~kg} \mathrm{P}_{2} \mathrm{O}_{5}+20 \mathrm{~kg} \mathrm{~K}_{2} \mathrm{O} \mathrm{ha}{ }^{-1}\right)\left(\mathrm{T}_{12}\right)$ to both rice and wheat. Six treatment are integrated integration of inorganic and organic sources i.e. $\left(\mathrm{T}_{6}\right) 50 \% \mathrm{RDF}+50 \% \mathrm{~N}$ through $\mathrm{FYM}$ to rice and $100 \% \mathrm{RDF}$ to wheat, $\left(\mathrm{T}_{7}\right) 75 \% \mathrm{RDF}$ $+25 \% \mathrm{~N}$ through FYM for rice and $75 \% \mathrm{RDF}$ to wheat, $\left(\mathrm{T}_{8}\right) 50 \% \mathrm{RDF}+50 \% \mathrm{~N}$ through crop residue to rice and $100 \%$ RDF to wheat, $\left(\mathrm{T}_{9}\right) 75 \% \mathrm{RDF}+25 \% \mathrm{~N}$ through crop residue to rice and $75 \%$ RDF to wheat, $\left(\mathrm{T}_{10}\right) 50 \%$ $\mathrm{RDF}+50 \% \mathrm{~N}$ through green leaf manuring to rice and $100 \% \mathrm{RDF}$ to wheat, $\left(\mathrm{T}_{11}\right) 75 \% \mathrm{RDF}$ $+25 \% \mathrm{~N}$ through green leaf manuring to rice and $75 \%$ RDF to wheat, along with one control having no nutrient nutrition application in either of the season $\left(\mathrm{T}_{1}\right)$. Rice variety HUR-105 and wheat variety HUW234 were selected for the study. The treatments (12) were arranged in randomized block design with 4 replications. Plot size was kept $11 \times 6 \mathrm{~m}^{2}$ (gross) and $10 \times 5 \mathrm{~m}^{2}$ (net) with $1 \mathrm{~m}$ plot border.

The observations on growth characters viz. plant height, LAI and SPAD value, dry matter accumulation, number of green leaves and number of tillers per hill for rice were recorded at 30, 60, 90 DAT and at harvest, and

\section{Growth of rice}

\section{Plant height $(\mathrm{cm})$}

It is apparent from table 1 that plant height increased progressively upto maturity stage. Plant height declined markedly with the curtailment of fertilizer doses from $100 \%$ RDF to both rice and wheat $\left(\mathrm{T}_{5}\right)$ to control at all the stages of observation. Being at par with 
$\mathrm{T}_{4}$ (75\% RDF to both rice and wheat), $\mathrm{T}_{5}$ recorded significantly higher plant height than lower doses of inorganic nutrient application $\left(\mathrm{T}_{12}, \mathrm{~T}_{3}, \mathrm{~T}_{2}\right.$, and $\left.\mathrm{T}_{1}\right)$. The plant height was highest in $\mathrm{T}_{6}(50 \% \mathrm{RDF}$ through fertilizers + $50 \% \mathrm{~N}$ through FYM to rice and $100 \%$ NPK through fertilizers to wheat) at all the stages of observation during both the years. Though, it did not show significant differences over $75 \% \mathrm{RDF}+25 \% \mathrm{~N}$ through FYM to rice and $75 \% \mathrm{RDF}$ to wheat $\left(\mathrm{T}_{7}\right), 50 \% \mathrm{RDF}+50 \% \mathrm{~N}$ through GM to rice and $100 \% \mathrm{RDF}$ to wheat $\left(\mathrm{T}_{10}\right), 75 \% \mathrm{RDF}+25 \% \mathrm{~N}$ through $\mathrm{GM}$ to rice and $75 \%$ RDF to wheat $\left(\mathrm{T}_{11}\right)$ and $100 \% \mathrm{RDF}$ to both rice and wheat $\left(\mathrm{T}_{5}\right)$ but produced significantly taller plants than $(50 \% \mathrm{RDF}+$ $50 \% \mathrm{~N}$ through wheat straw to rice and $100 \%$ RDF to wheat $\left(\mathrm{T}_{8}\right)$ and $75 \% \mathrm{RDF}+25 \% \mathrm{~N}$ through wheat straw to rice and $75 \% \mathrm{RDF}$ to wheat $\left(\mathrm{T}_{9}\right)$ at most of the stages during both the years.

\section{Number of tillers hill ${ }^{-1}$}

The number of tillers hill ${ }^{-1}$ increased upto 60 DAT and thereafter showed a declining trend till maturity. Increasing levels of fertilizer application upto $100 \% \mathrm{RDF}$ to both the crops in sequence $\left(T_{5}\right)$, showed marked improvement in number of tillers hill ${ }^{-1}$ at all stages during both the years. Though, $\mathrm{T}_{5}$ remained par with $\mathrm{T}_{4}(75 \% \mathrm{RDF}$ to both rice and wheat) both produced significantly more number of tillers hill ${ }^{-1}$ than other treatments involving inorganic sources of nutrients and control (Table 2). Highest number of tillers hill $^{-1}$ were recorded under $\mathrm{T}_{6}(50 \% \mathrm{RDF}+$ $50 \% \mathrm{~N}$ through FYM to rice accompanied with $100 \%$ RDF to wheat) at all the stages during both the years. However, it did not differ significentlyT $\mathrm{T}_{7}(75 \% \mathrm{RDF}+25 \% \mathrm{~N}$ through FYM to rice and $75 \%$ RDF to wheat) and $\mathrm{T}_{10}(50 \% \mathrm{RDF}+50 \% \mathrm{~N}$ through green manure to rice and $100 \%$ RDF to wheat). Farmer's practice of fertilizer application $\left(T_{12}\right)$ also recorded insignificantly higher in number of tillers hill ${ }^{-1}$ over the control $\left(\mathrm{T}_{1}\right)$ at maturity during both the years.

\section{Number of green leaves hill ${ }^{-1}$}

The data presented in table 3 revealed that the number of green leaves hill-1 increased upto 60 DAT and thereafter decreased at 90 DAT. Increasing levels of fertilizer application upto $100 \%$ RDF to both the crops in sequence $\left(\mathrm{T}_{5}\right)$, showed marked increase in number of green leaves hill ${ }^{-1}$ at all stages during both the year (Table 3). Nevertheless, $T_{5}$ did not differ statistically with $\mathrm{T}_{4}$ (75\% RDF to both rice and wheat). Highest number of green leaves hill $^{-1}$ were recorded under $\mathrm{T}_{6}(50 \% \mathrm{RDF}+$ $50 \% \mathrm{~N}$ through FYM to rice accompanied with $100 \% \mathrm{RDF}$ to wheat) at all the stages during both the years. However, it did not differ significantly with $\mathrm{T}_{7}(75 \% \mathrm{RDF}+25 \%$ $\mathrm{N}$ through FYM to rice and $75 \% \mathrm{RDF}$ to wheat), $\mathrm{T}_{10}(50 \% \mathrm{RDF}+50 \% \mathrm{~N}$ through green manure to rice and $100 \% \mathrm{RDF}$ to wheat) and $\mathrm{T}_{11}(75 \% \mathrm{RDF}+25 \% \mathrm{~N}$ through green manure to rice and $75 \% \mathrm{RDF}$ to wheat). Farmer's practice $\left(\mathrm{T}_{12}\right)$ also produced higher in number of green leaves hill ${ }^{-1}$ over $\mathrm{T}_{2}(50 \%$ RDF to both rice and wheat) and control $\left(\mathrm{T}_{1}\right)$ and the difference were significant at maturity during both the years.

\section{Dry matter accumulation}

It is apparent from table 4 that dry matter accumulation increased progressively upto maturity stage. Marked declined in dry matter production was observed with decreasing levels of fertilizer application from $\mathrm{T}_{5}(100 \%$ $\mathrm{RDF}$ to both rice and wheat) to $\mathrm{T}_{1}$ (control) during both the years. Being comparable to $\mathrm{T}_{4}$ (75\% RDF to both rice and wheat) $\mathrm{T}_{5}$ produced significantly higher dry matter hill ${ }^{-1}$ than other treatments of inorganic nutrient sources except farmer's practice at taller stages. The higher dry matter accumulation was recorded under $\mathrm{T}_{6}(50 \% \mathrm{RDF}+50 \% \mathrm{~N}$ 
through FYM to rice and $100 \%$ RDF to wheat) significantly, though, it remained at par to $\mathrm{T}_{7}(75 \% \mathrm{RDF}+25 \% \mathrm{~N}$ through $\mathrm{FYM}$ to rice and $75 \% \mathrm{RDF}$ to wheat), $\mathrm{T}_{10}(50 \% \mathrm{RDF}+$ $50 \% \mathrm{~N}$ through green manure to rice and $100 \% \mathrm{RDF}$ to wheat) and $\mathrm{T}_{11}(75 \% \mathrm{RDF}+$ $25 \% \mathrm{~N}$ through green manure to rice and $75 \%$ $\mathrm{RDF}$ to wheat) produced significantly superior to other treatments at all the stages during both the years.

Farmer's practice of fertilizer application $\left(T_{12}\right)$ was significantly superior to control $\left(T_{1}\right)$ and inferior to most of the treatments during both the years.

\section{SPAD value}

As number the number of green leaf hill $^{-1}$ the chlorophyll content in terms of SPAD also increased upto 60 DAT and thereafter decreased at 90 DAT.

Decreasing levels of fertilizer application from $\mathrm{T}_{5}$ (100\% RDF both rice and wheat) to $\mathrm{T}_{1}$ (control) decreased SPAD value in leaves (Table 5). However, there was no significant difference between $\mathrm{T}_{5}$ and $\mathrm{T}_{4}(75 \%$ RDF both to rice and wheat) at any of the stages in during two years of experimentation.

Highest SPAD vale was recorded under $\mathrm{T}_{6}$ $(50 \% \mathrm{RDF}+50 \% \mathrm{~N}$ through FYM to rice accompanied with $100 \%$ RDF to wheat) at all the stages during both the years.

Nevertheless, it did not differ significantly with $\mathrm{T}_{7}(75 \% \mathrm{RDF}+25 \% \mathrm{~N}$ through FYM to rice and $75 \% \mathrm{RDF}$ to wheat), $\mathrm{T}_{10}(50 \% \mathrm{RDF}+$ $50 \% \mathrm{~N}$ through green manure to rice and $100 \%$ RDF to wheat) and $\mathrm{T}_{11}(75 \% \mathrm{RDF}+$ $25 \% \mathrm{~N}$ through green manure to rice and $75 \%$ RDF to wheat). Farmer's practice of fertilizer application $\left(T_{12}\right)$ was significantly superior to control $\left(\mathrm{T}_{1}\right)$ and inferior to most of the treatments during both the years.

\section{Leaf area index}

Leaf area index as influenced by various inorganic and organic sources of nutrient application at different growth stages are presented in table 6. Perusal of the data revealed that leaf area index was markedly affected by different treatments at 30,60 and 90 DAT during both the years. Leaf area index increased upto 60 DAT and declined at 90 DAT.

Decreasing doses of inorganic nutrient application from $\mathrm{T}_{5}(100 \% \mathrm{RDF}$ to both rice and wheat) to $T_{1}$ (control) resulted in corresponding decrease in leaf are index at 30, 60 and 90 DAT during both the years. Nevertheless, $\mathrm{T}_{5}$ remained comparable to $\mathrm{T}_{4}$ (75\% RDF to both rice and wheat) at almost all the stages of observation.

Maximum leaf area index was recorded under $\mathrm{T}_{6}(50 \% \mathrm{RDF}+50 \% \mathrm{~N}$ through FYM to rice accompanied with $100 \%$ RDF to wheat) and being at par with $\mathrm{T}_{7}(75 \% \mathrm{RDF}+25 \% \mathrm{~N}$ through FYM to rice and $75 \% \mathrm{RDF}$ to wheat), it recorded markedly higher LAI than other treatments.

However, it did not differ significantly to $\mathrm{T}_{5}$, $\mathrm{T}_{10}$ and $\mathrm{T}_{11}$ at 30 DAT and $\mathrm{T}_{10}$ and $\mathrm{T}_{11}$ at 60 DAT. Farmer's practice of fertilizer application $\left(\mathrm{T}_{12}\right)$ was significantly superior to control $\left(\mathrm{T}_{1}\right)$ and inferior to most of the treatments during both the years.

\section{Development stages}

\section{Day to $50 \%$ panicle emergence}

It is apparent from the Data present in table 7 that the number of days taken for $50 \%$ panicle emergence after transplanting was significantly influenced under different treatments. 
It was recorded earliest in $\mathrm{T} 6(50 \% \mathrm{RDF}+$ $50 \% \mathrm{~N}$ through FYM) to rice $+100 \% \mathrm{RDF}$ to wheat), whereas, control $\left(\mathrm{T}_{1}\right)$ take maximum period.

Though, $\mathrm{T}_{6}$ remained comparable to $\mathrm{T}_{7}, \mathrm{~T}_{10}$ and $\mathrm{T}_{5}$ attained $50 \%$ panicle emergence in significantly less period than $T_{1}, T_{2}$ and $T_{12}$ during both the years.

\section{Days to maturity}

The maturity of rice was also significantly affected by fertilizer levels and integrated nutrient management treatments. Application of fertilizer significantly hastened the crop maturity during both the years (Table 7).

Days taken to maturity after transplanting was lowest in treatment where $50 \%$ RDF was applied through fertilizers $+50 \% \mathrm{~N}$ through FYM to rice and $100 \%$ RDF to wheat $\left(\mathrm{T}_{6}\right)$ but it could show significant superiority only over $\mathrm{T}_{1}, \mathrm{~T}_{2}$ and $\mathrm{T}_{12}$ during both the years and over $\mathrm{T}_{3}$ during 2011 in reducing the maturity period. Crop maturity was significantly prolonged when no fertilizer and manure were applied $\left(\mathrm{T}_{1}\right)$.

\section{Results and Discussion}

Data on growth of rice at periodic intervals revealed that as compared to control and application of nutrients through inorganic fertilizers the INM treatments progressively improved all the growth parameters.

Organic manure application release nutrients slowly and gave favourable conditions to plant that is associated to Vigorous growth and higher growth rate.

The plant height in both the crops during both the years continued to increase with age and there was no further increase as crop proceeded towards maturity, while dry matter accumulation increased upto maturity because of accumulation of photosynthates in sink. Number of tillers in both the crops was increased only upto 90 days of transplanting /sowing and number of leaves, chrolophyll content and leaf area index increased only upto 60 days after transplanting / sowing, thereafter, there was no increase in tillers, leaves, chrolophyll and leaf area index upto maturity.

Addition of different organic materials like Sesbania green manure, FYM and compost enhanced the organic matter percentage of the soil that played a key role for improving soil fertility and crop growth.

The increase in organic matter content of soil improved the physical properties of the soil. The betterment in physical properties of soil reduced the soil $\mathrm{pH}$ as various acid and acid forming compounds were released with the addition of organic materials.

The reduction in soil $\mathrm{pH}$ increased the availability of plant nutrients and resultantly more uptake of various nutrients by the plants occurred. The increased uptake of nutrients by rice improved metabolic activities in the plants.. As a result of all above processes growth of rice was positively affected. (Mehdi et al., 2011)

The soil organic matter is measured to be the panacea for plant life by high calibre of being a source of almost all the essential macro and micronutrients.

The organic manures good provider of $\mathrm{N}, \mathrm{P}$, $\mathrm{K}$ and also added other essential macro and micronutrients for plant growth. In association with soil micro-organisms, organic manures are also help in synthesis of certain phytohormones and vitamins which promote the growth and development of crops (Sharma, 1983). 
Table.1 Effect of Integrated Nutrient Management on plant height $(\mathrm{cm})$ of rice

\begin{tabular}{|c|c|c|c|c|c|c|c|c|c|}
\hline \multirow{2}{*}{\multicolumn{2}{|c|}{ Treatments }} & \multicolumn{2}{|c|}{30 DAT } & \multicolumn{2}{|c|}{60 DAT } & \multicolumn{2}{|c|}{90 DAT } & \multicolumn{2}{|c|}{ At Harvest } \\
\hline & & 2010 & 2011 & 2010 & 2011 & 2010 & 2011 & 2010 & 2011 \\
\hline $\mathbf{T}_{1}$ Control* & Control & 38.70 & 39.65 & 60.86 & 62.96 & 73.80 & 75.61 & 75.50 & 76.60 \\
\hline $\mathbf{T}_{2} 50 \%$ RF & $50 \%$ RF & 39.60 & 40.57 & 67.89 & 70.23 & 76.75 & 78.63 & 82.50 & 83.70 \\
\hline $\mathbf{T}_{3} \mathbf{5 0 \%}$ RF & $100 \%$ RF & 40.50 & 41.49 & 70.50 & 72.93 & 79.90 & 81.86 & 84.99 & 86.22 \\
\hline $\mathbf{T}_{4} 75 \%$ RF & $75 \%$ RF & 46.70 & 47.84 & 78.95 & 81.67 & 86.58 & 88.70 & 92.01 & 93.35 \\
\hline $\mathrm{T}_{5} \mathbf{1 0 0 \%} \mathrm{RF}$ & $100 \%$ RF & 47.50 & 49.14 & 82.04 & 85.69 & 92.05 & 95.23 & 96.21 & 98.57 \\
\hline $\mathrm{T}_{6} 50 \% \mathrm{RF}+50 \% \mathrm{~N}$ through FYM & $100 \%$ RF & 50.45 & 52.19 & 86.88 & 90.75 & 100.03 & 103.48 & 107.38 & 110.01 \\
\hline $\mathrm{T}_{7} 75 \% \mathrm{RF}+25 \% \mathrm{~N}$ through FYM & $75 \% \mathbf{R F}$ & 48.65 & 50.33 & 83.65 & 87.37 & 96.30 & 99.62 & 105.77 & 108.36 \\
\hline $\mathrm{T}_{8} 50 \% \mathrm{RF}+50 \% \mathrm{~N}$ through $\mathrm{CR}$ & $100 \%$ RF & 41.78 & 42.80 & 72.47 & 74.97 & 80.35 & 82.32 & 85.08 & 86.31 \\
\hline $\mathrm{T}_{9} 75 \% \mathrm{RF}+25 \% \mathrm{~N}$ through $\mathrm{CR}$ & $75 \%$ RF & 47.10 & 48.25 & 79.90 & 82.66 & 87.80 & 89.95 & 93.44 & 94.80 \\
\hline $\mathrm{T}_{10} 50 \% \mathrm{RF}+50 \% \mathrm{~N}$ through GM & $100 \%$ RF & 47.90 & 49.55 & 83.06 & 86.76 & 95.35 & 98.64 & 100.44 & 102.90 \\
\hline$T_{11} 75 \%$ RF $+25 \% \mathrm{~N}$ through GM & $75 \%$ RF & 47.45 & 49.09 & 82.11 & 85.76 & 94.85 & 98.12 & 99.60 & 102.04 \\
\hline $\mathbf{T}_{12}$ Farmer's practice ${ }^{* *}$ & & 41.35 & 42.37 & 70.68 & 73.12 & 78.88 & 80.81 & 82.82 & 84.02 \\
\hline SEM+ & & 1.64 & 1.92 & 2.92 & 3.32 & 3.18 & 3.74 & 3.76 & 3.93 \\
\hline CD at $5 \%$ & & 4.73 & 5.53 & 8.40 & 9.56 & 9.14 & $\mathbf{1 0 . 7 5}$ & 10.81 & 11.32 \\
\hline
\end{tabular}

Table.2 Effect of Integrated Nutrient Management on number of tillers hill ${ }^{-1}$ of rice

\begin{tabular}{|c|c|c|c|c|c|c|c|c|c|}
\hline \multirow{2}{*}{\multicolumn{2}{|c|}{ Treatments }} & \multicolumn{2}{|c|}{ 30 DAT } & \multicolumn{2}{|c|}{60 DAT } & \multicolumn{2}{|c|}{90 DAT } & \multicolumn{2}{|c|}{ At Harvest } \\
\hline & & 2010 & 2011 & 2010 & 2011 & 2010 & 2011 & 2010 & 2011 \\
\hline $\mathbf{T}_{1}$ Control* & Control & 8.63 & 9.15 & 10.63 & 11.11 & 9.53 & 9.10 & 7.92 & 8.41 \\
\hline $\mathrm{T}_{2} \mathbf{5 0 \%} \mathrm{RF}$ & $50 \%$ RF & 9.19 & 9.57 & 11.19 & 11.66 & 10.19 & 10.66 & 9.10 & 9.52 \\
\hline $\mathrm{T}_{3} \mathbf{5 0 \%} \mathrm{RF}$ & $100 \%$ RF & 10.75 & 11.15 & 12.75 & 12.82 & 11.55 & 11.55 & 10.35 & 10.70 \\
\hline $\mathrm{T}_{4} \mathbf{7 5 \%} \mathrm{RF}$ & $75 \%$ RF & 12.44 & 12.59 & 15.44 & 15.22 & 13.94 & 13.97 & 12.87 & 13.02 \\
\hline $\mathrm{T}_{5} \mathbf{1 0 0 \%} \mathrm{RF}$ & $100 \%$ RF & 12.50 & 12.78 & 15.50 & 15.52 & 14.00 & 14.27 & 12.92 & 13.04 \\
\hline $\mathrm{T}_{6} \mathbf{5 0 \%} \mathrm{RF}+50 \% \mathrm{~N}$ through FYM & $100 \%$ RF & 15.47 & 15.51 & 19.47 & 19.49 & 17.47 & 17.58 & 16.13 & 16.32 \\
\hline $\mathrm{T}_{7} \mathbf{7 5 \%} \mathrm{RF}+25 \% \mathrm{~N}$ through FYM & $75 \%$ RF & 15.13 & 15.23 & 19.13 & 18.86 & 17.13 & 16.86 & 15.81 & 15.69 \\
\hline $\mathrm{T}_{8} 50 \% \mathrm{RF}+50 \% \mathrm{~N}$ through CR & $100 \%$ RF & 11.88 & 12.25 & 14.88 & 15.03 & 13.38 & 13.38 & 12.35 & 12.56 \\
\hline $\mathrm{T}_{9} \mathbf{7 5} \% \mathrm{RF}+25 \% \mathrm{~N}$ through $\mathrm{CR}$ & $75 \%$ RF & 12.19 & 12.40 & 15.19 & 15.44 & 13.69 & 13.69 & 12.64 & 12.87 \\
\hline $\mathrm{T}_{10} 50 \% \mathrm{RF}+50 \% \mathrm{~N}$ through GM & $100 \%$ RF & 14.19 & 14.43 & 18.19 & 18.69 & 16.19 & 16.44 & 14.94 & 14.60 \\
\hline $\mathrm{T}_{11} \mathbf{7 5 \%} \mathrm{RF}+\mathbf{2 5 \%} \mathrm{N}$ through GM & $75 \%$ RF & 12.63 & 12.78 & 15.63 & 15.84 & 14.13 & 14.09 & 13.04 & 13.23 \\
\hline $\mathbf{T}_{12}$ Farmer's practice $* *$ & & 9.44 & 10.07 & 11.44 & 11.59 & 10.44 & 10.47 & 9.44 & 9.70 \\
\hline SEM+ & & 0.515 & 0.47 & 0.643 & 0.92 & 0.576 & $\mathbf{0 . 8 0}$ & 0.530 & 0.55 \\
\hline CD at $5 \%$ & & 1.482 & 1.34 & 1.849 & 2.66 & 1.657 & 2.29 & 1.525 & 1.59 \\
\hline
\end{tabular}


Table.3 Effect of Integrated Nutrient Management on number of green leaves hill ${ }^{-1}$ of rice

\begin{tabular}{|c|c|c|c|c|c|c|c|}
\hline \multirow{2}{*}{\multicolumn{2}{|c|}{ Treatments }} & \multicolumn{2}{|c|}{ 30 DAT } & \multicolumn{2}{|c|}{ 60 DAT } & \multicolumn{2}{|c|}{90 DAT } \\
\hline & & 2010 & 2011 & 2010 & 2011 & 2010 & 2011 \\
\hline $\mathbf{T}_{1}$ Control* $^{*}$ & Control & 15.01 & 15.06 & 30.30 & 33.76 & 17.76 & 18.17 \\
\hline $\mathrm{T}_{2} \mathbf{5 0 \%} \mathrm{RF}$ & $50 \%$ RF & 16.51 & 17.02 & 33.00 & 36.46 & 20.16 & 22.09 \\
\hline $\mathrm{T}_{3} \mathbf{5 0 \%} \mathrm{RF}$ & $100 \%$ RF & 17.23 & 18.49 & 34.95 & 37.42 & 25.65 & 26.14 \\
\hline $\mathrm{T}_{4} \mathbf{7 5 \%} \mathrm{RF}$ & $75 \%$ RF & 18.73 & 20.17 & 37.76 & 40.04 & 27.81 & 28.94 \\
\hline $\mathrm{T}_{5} \mathbf{1 0 0 \%} \mathrm{RF}$ & $100 \%$ RF & 19.17 & 20.58 & 39.10 & 41.56 & 28.63 & 29.54 \\
\hline $\mathrm{T}_{6} \mathbf{5 0 \%} \mathrm{RF}+\mathbf{5 0 \%} \mathrm{N}$ through FYM & $100 \%$ RF & 23.50 & 24.61 & 47.40 & 49.86 & 34.41 & 35.29 \\
\hline $\mathrm{T}_{7} 75 \% \mathrm{RF}+25 \% \mathrm{~N}$ through FYM & $75 \%$ RF & 23.15 & 23.94 & 45.05 & 46.51 & 32.26 & 32.99 \\
\hline $\mathrm{T}_{8} \mathbf{5 0 \%} \mathrm{RF}+\mathbf{5 0} \% \mathrm{~N}$ through CR & $100 \%$ RF & 17.90 & 18.74 & 36.10 & 38.41 & 25.95 & 26.51 \\
\hline $\mathrm{T}_{9} 75 \% \mathrm{RF}+25 \% \mathrm{~N}$ through $\mathrm{CR}$ & $75 \%$ RF & 20.65 & 22.27 & 39.15 & 40.61 & 28.56 & 29.39 \\
\hline $\mathrm{T}_{10} \mathbf{5 0 \%} \mathrm{RF}+\mathbf{5 0 \%} \mathrm{N}$ through GM & $100 \%$ RF & 21.85 & 23.31 & 41.85 & 43.31 & 30.11 & 31.09 \\
\hline $\mathrm{T}_{11} 75 \% \mathrm{RF}+25 \% \mathrm{~N}$ through GM & $75 \%$ RF & 21.80 & 23.14 & 41.70 & 43.16 & 29.61 & 30.44 \\
\hline $\mathbf{T}_{12}$ Farmer's practice ${ }^{* *}$ & & 18.24 & 19.12 & 37.18 & 39.61 & 26.51 & 27.76 \\
\hline SEM+ & & $\mathbf{0 . 8 2}$ & 0.86 & 1.62 & 1.71 & 1.16 & 1.19 \\
\hline CD at 5\% & & 2.35 & 2.47 & 4.67 & 4.93 & 3.32 & 3.43 \\
\hline
\end{tabular}

Table.4 Effect of Integrated Nutrient Management on dry matter $(\mathrm{g})$ hill $^{-1}$ of rice

\begin{tabular}{|c|c|c|c|c|c|c|c|c|c|}
\hline \multirow{2}{*}{\multicolumn{2}{|c|}{ Treatments }} & \multicolumn{2}{|c|}{30 DAT } & \multicolumn{2}{|c|}{ 60 DAT } & \multicolumn{2}{|c|}{90 DAT } & \multicolumn{2}{|c|}{ At Harvest } \\
\hline & & 2010 & 2011 & 2010 & 2011 & 2010 & 2011 & 2010 & 2011 \\
\hline $\mathbf{T}_{1}$ Control* & Control & 8.65 & 9.04 & 21.48 & 24.31 & 41.59 & 45.13 & 47.93 & 50.97 \\
\hline $\mathrm{T}_{2} \mathbf{5 0 \%} \mathrm{RF}$ & $50 \%$ RF & 9.21 & 9.67 & 22.88 & 25.59 & 48.26 & 51.69 & 55.61 & 58.85 \\
\hline $\mathrm{T}_{3} 50 \% \mathrm{RF}$ & $100 \%$ RF & 10.12 & 10.87 & 25.15 & 28.08 & 53.09 & 54.70 & 61.18 & 64.98 \\
\hline $\mathrm{T}_{4} 75 \% \mathrm{RF}$ & $75 \%$ RF & 11.04 & 11.75 & 27.45 & 29.64 & 58.29 & 57.54 & 67.17 & 70.67 \\
\hline $\mathrm{T}_{5} \mathbf{1 0 0 \%} \mathrm{RF}$ & $100 \%$ RF & 11.45 & 12.17 & 28.48 & 30.23 & 60.11 & 58.45 & 69.27 & 72.56 \\
\hline $\mathrm{T}_{6} \mathbf{5 0 \%} \mathrm{RF}+50 \% \mathrm{~N}$ through FYM & $100 \%$ RF & 12.84 & 13.90 & 31.95 & 34.61 & 67.99 & 67.52 & 77.85 & 82.12 \\
\hline $\mathrm{T}_{7} \mathbf{7 5 \%} \mathrm{RF}+25 \% \mathrm{~N}$ through FYM & $75 \%$ RF & 12.66 & 13.52 & 31.15 & 34.17 & 65.67 & 54.30 & 75.68 & 79.63 \\
\hline $\mathrm{T}_{8} \mathbf{5 0 \%} \mathrm{RF}+\mathbf{5 0 \%} \mathrm{N}$ through CR & $100 \%$ RF & 10.34 & 11.16 & 25.70 & 28.39 & 56.07 & 62.39 & 64.62 & 68.08 \\
\hline $\mathrm{T}_{9} \mathbf{7 5 \%} \mathrm{RF}+25 \% \mathrm{~N}$ through CR & $75 \%$ RF & 10.75 & 11.54 & 26.73 & 29.41 & 57.05 & 60.61 & 65.74 & 68.88 \\
\hline $\mathrm{T}_{10} \mathbf{5 0 \%} \mathrm{RF}+\mathbf{5 0 \%} \mathrm{N}$ through GM & $100 \%$ RF & 12.14 & 13.06 & 30.20 & 30.81 & 62.91 & 68.14 & 72.49 & 76.55 \\
\hline $\mathrm{T}_{11} 75 \% \mathrm{RF}+25 \% \mathrm{~N}$ through GM & $75 \%$ RF & 11.88 & 12.42 & 29.55 & 32.50 & 61.47 & 62.48 & 70.83 & 74.50 \\
\hline $\mathbf{T}_{12}$ Farmer's practice $* *$ & & 9.82 & 10.63 & 24.40 & 27.14 & 53.73 & 55.48 & 61.92 & 65.05 \\
\hline SEM+ & & 0.46 & 0.43 & 1.14 & 1.44 & 2.41 & 3.07 & 2.74 & 2.76 \\
\hline CD at $5 \%$ & & 1.32 & 1.24 & 3.27 & 4.16 & 6.92 & 8.82 & 7.88 & 7.93 \\
\hline
\end{tabular}


Table.5 Effect of Integrated Nutrient Management on chlorophyll content of rice

\begin{tabular}{|c|c|c|c|c|c|c|c|}
\hline \multirow{2}{*}{\multicolumn{2}{|c|}{ Treatments }} & \multicolumn{2}{|c|}{ 30 DAT } & \multicolumn{2}{|c|}{ 60 DAT } & \multicolumn{2}{|c|}{90 DAT } \\
\hline & & 2010 & 2011 & 2010 & 2011 & 2010 & 2011 \\
\hline $\mathbf{T}_{1}$ Control* $^{*}$ & Control & 24.59 & 25.51 & 25.69 & 26.08 & 19.65 & 20.10 \\
\hline $\mathrm{T}_{2} \mathbf{5 0 \%} \mathrm{RF}$ & $50 \%$ RF & 26.05 & 26.70 & 27.22 & 27.41 & 21.28 & 21.68 \\
\hline $\mathrm{T}_{3} \mathbf{5 0 \%} \mathrm{RF}$ & $100 \%$ RF & 27.64 & 28.25 & 28.89 & 29.46 & 23.05 & 23.47 \\
\hline $\mathrm{T}_{4} \mathbf{7 5 \%} \mathrm{RF}$ & $75 \%$ RF & 31.73 & 32.48 & 33.18 & 33.64 & 25.54 & 25.62 \\
\hline $\mathrm{T}_{5} 100 \% \mathrm{RF}$ & $100 \%$ RF & 32.34 & 33.04 & 33.82 & 34.35 & 26.05 & 26.22 \\
\hline $\mathrm{T}_{6} 50 \% \mathrm{RF}+50 \% \mathrm{~N}$ through FYM & $100 \%$ RF & 36.22 & 37.61 & 37.89 & 38.56 & 29.31 & 29.78 \\
\hline $\mathrm{T}_{7} 75 \% \mathrm{RF}+25 \% \mathrm{~N}$ through FYM & $75 \%$ RF & 33.84 & 34.92 & 35.39 & 36.27 & 28.23 & 28.96 \\
\hline $\mathrm{T}_{8} \mathbf{5 0 \%} \mathrm{RF}+50 \% \mathrm{~N}$ through $\mathrm{CR}$ & $100 \%$ RF & 28.94 & 30.27 & 30.26 & 30.97 & 23.84 & 24.20 \\
\hline $\mathrm{T}_{9} 75 \% \mathrm{RF}+25 \% \mathrm{~N}$ through $\mathrm{CR}$ & $75 \%$ RF & 30.12 & 31.61 & 31.49 & 32.67 & 24.71 & 25.29 \\
\hline $\mathrm{T}_{10} \mathbf{5 0 \%} \mathrm{RF}+\mathbf{5 0 \%} \mathrm{N}$ through GM & $100 \%$ RF & 33.05 & 34.05 & 34.56 & 35.24 & 27.35 & 28.21 \\
\hline $\mathrm{T}_{11} 75 \% \mathrm{RF}+25 \% \mathrm{~N}$ through GM & $75 \%$ RF & 32.69 & 33.60 & 34.18 & 34.98 & 26.67 & 27.46 \\
\hline $\mathbf{T}_{12}$ Farmer's practice ${ }^{* *}$ & & 26.65 & 30.98 & 27.85 & 28.29 & 21.62 & 21.86 \\
\hline SEM+ & & 1.27 & 1.32 & 1.33 & 1.30 & 1.04 & 1.10 \\
\hline CD at 5\% & & 3.66 & 3.81 & 3.83 & 3.75 & 2.99 & 3.17 \\
\hline
\end{tabular}

Table.6 Effect of Integrated Nutrient Management on leaf area index of rice

\begin{tabular}{|c|c|c|c|c|c|c|c|}
\hline \multirow{2}{*}{\multicolumn{2}{|c|}{ Treatments }} & \multicolumn{2}{|c|}{30 DAT } & \multicolumn{2}{|c|}{60 DAT } & \multicolumn{2}{|c|}{90 DAT } \\
\hline & & 2010 & 2011 & 2010 & 2011 & 2010 & 2011 \\
\hline $\mathbf{T}_{1}$ Control* & Control & 1.50 & 1.57 & 4.28 & 4.47 & 3.08 & 3.20 \\
\hline $\mathbf{T}_{2} \mathbf{5 0 \%} \mathbf{R F}$ & $50 \%$ RF & 1.53 & 1.60 & 4.63 & 5.15 & 3.19 & 3.28 \\
\hline $\mathbf{T}_{\mathbf{3}} \mathbf{5 0 \%} \mathbf{R F}$ & $100 \%$ RF & 1.65 & 1.73 & 5.32 & 5.58 & 3.78 & 4.01 \\
\hline $\mathrm{T}_{4} \mathbf{7 5 \%} \mathrm{RF}$ & $75 \%$ RF & 1.61 & 1.69 & 5.19 & 5.43 & 3.62 & 3.82 \\
\hline $\mathrm{T}_{5} \mathbf{1 0 0 \%} \mathrm{RF}$ & $100 \%$ RF & 1.70 & 1.79 & 5.42 & 5.65 & 4.30 & 4.57 \\
\hline $\mathbf{T}_{6} 50 \% \mathrm{RF}+50 \% \mathrm{~N}$ through FYM & $100 \%$ RF & 1.93 & 2.03 & 6.20 & 6.54 & 4.81 & 5.14 \\
\hline $\mathrm{T}_{7} \mathbf{7 5 \%} \mathrm{RF}+25 \% \mathrm{~N}$ through FYM & $75 \%$ RF & 1.89 & 2.00 & 6.09 & 6.44 & 4.69 & 5.01 \\
\hline $\mathrm{T}_{8} \mathbf{5 0 \%} \mathrm{RF}+\mathbf{5 0} \% \mathrm{~N}$ through CR & $100 \%$ RF & 1.70 & 1.79 & 5.48 & 5.77 & 3.94 & 4.20 \\
\hline $\mathrm{T}_{9} 75 \% \mathrm{RF}+25 \% \mathrm{~N}$ through CR & $75 \%$ RF & 1.67 & 1.74 & 5.37 & 5.61 & 3.86 & 4.07 \\
\hline$T_{10} 50 \%$ RF + 50\% N through GM & $100 \%$ RF & 1.78 & 1.89 & 5.73 & 6.08 & 4.20 & 4.51 \\
\hline $\mathrm{T}_{11} \mathbf{7 5 \%} \mathrm{RF}+25 \% \mathrm{~N}$ through GM & $75 \%$ RF & 1.74 & 1.82 & 5.60 & 5.87 & 4.00 & 4.24 \\
\hline $\mathbf{T}_{12}$ Farmer's practice ${ }^{* *}$ & & 1.55 & 1.62 & 4.99 & 5.22 & 3.41 & 3.40 \\
\hline SEM+ & & 0.07 & 0.07 & 0.22 & 0.22 & 0.16 & 0.17 \\
\hline CD at $5 \%$ & & 0.20 & 0.20 & 0.65 & 0.64 & 0.47 & 0.48 \\
\hline
\end{tabular}


Table.7 Effect of Integrated Nutrient Management on days to flowering and maturity of rice

\begin{tabular}{|c|c|c|c|c|c|}
\hline \multirow{2}{*}{ Treatments } & & \multicolumn{2}{|c|}{ Days to $50 \%$ Flowering DAT } & \multicolumn{2}{|c|}{ Days to Maturity DAT } \\
\hline & & 2010 & 2011 & 2010 & 2011 \\
\hline $\mathbf{T}_{1}$ Control* & Control & 78.25 & 78.50 & 105.75 & 108.00 \\
\hline $\mathrm{T}_{2} \mathbf{5 0 \%} \mathrm{RF}$ & $50 \%$ RF & 75.75 & 76.00 & 103.75 & 105.75 \\
\hline $\mathrm{T}_{3} \mathbf{5 0 \%} \mathbf{R F}$ & $100 \%$ RF & 72.75 & 74.25 & 100.75 & 103.75 \\
\hline $\mathrm{T}_{4} \mathbf{7 5 \%} \mathrm{RF}$ & $75 \%$ RF & 72.50 & 74.00 & 100.25 & 104.00 \\
\hline $\mathrm{T}_{5} \mathbf{1 0 0 \%} \mathrm{RF}$ & $100 \% \mathrm{RF}$ & 72.25 & 72.25 & 100.25 & 102.00 \\
\hline $\mathrm{T}_{6} \mathbf{5 0 \%} \mathrm{RF}+\mathbf{5 0 \%} \mathrm{N}$ through FYM & $100 \% \mathrm{RF}$ & 71.25 & 71.50 & 99.75 & 100.25 \\
\hline $\mathrm{T}_{7} 75 \% \mathrm{RF}+25 \% \mathrm{~N}$ through FYM & $75 \% \mathrm{RF}$ & 71.25 & 72.00 & 99.75 & 101.25 \\
\hline $\mathrm{T}_{8} \mathbf{5 0 \%} \mathrm{RF}+\mathbf{5 0 \%} \mathrm{N}$ through $\mathrm{CR}$ & $100 \%$ RF & 72.75 & 74.25 & 100.75 & 102.50 \\
\hline $\mathrm{T}_{9} \mathbf{7 5} \% \mathrm{RF}+25 \% \mathrm{~N}$ through $\mathrm{CR}$ & $75 \%$ RF & 72.50 & 74.00 & 100.25 & 102.75 \\
\hline $\mathrm{T}_{10} \mathbf{5 0 \%} \mathrm{RF}+\mathbf{5 0 \%} \mathrm{N}$ through GM & $100 \%$ RF & 71.50 & 73.00 & 100.00 & 101.50 \\
\hline $\mathrm{T}_{11} \mathbf{7 5 \%} \mathrm{RF}+25 \% \mathrm{~N}$ through $\mathrm{GM}$ & $75 \% \mathrm{RF}$ & 72.25 & 73.50 & 100.00 & 102.00 \\
\hline $\mathbf{T}_{12}$ Farmer's practice** & & 74.50 & 75.00 & 102.50 & 104.25 \\
\hline SEM+ & & 0.99 & 0.67 & 0.75 & 1.04 \\
\hline CD at $5 \%$ & & 2.86 & 1.94 & 2.15 & 2.98 \\
\hline
\end{tabular}




\section{Development stages}

The number of days taken for heading/flowering and maturity in both the crops were hastened in the plots manured with conjoint application of organics [FYM, green manure (dhaincha) and wheat cut straw] and fertilizers in rice as well as succeeding wheat crop due to the direct and residual effect (Mehta, 2004). This is because conjoint application of organics and chemical fertilizers resulted in early boost of vegetative growth due to better nutrition and thus, the attainment of physiological stages was enhanced. These findings are in agreement with Shah et al., (1998).

The experimental finding indicated that the growth attributes viz: plant hight $(\mathrm{cm})$, number of tillers hill-1, numbers of green leaf hill-1, Dry matter g hill-1, LAI, and chlorophyll content was markedly decline with curtailment in level of chemical fertilizer from $100 \% \mathrm{RDF}$ to both rice and wheat $\left(\mathrm{T}_{5}\right)$ to control $\left(\mathrm{T}_{1}\right)$. All the Growth attributing character recorded highest value in $\mathrm{T}_{6}$ where $50 \% \mathrm{RDF}+50 \% \mathrm{~N}$ through $\mathrm{FYM}$ was applied to rice accompanied with $100 \% \mathrm{RDF}$ to wheat. The minimum value was observed in $\mathrm{T}_{1}$ (Control). However, decreasing in level of inorganic sources from $100 \%$ RDF to both rice and wheat $\left(\mathrm{T}_{5}\right)$ to Control $\left(\mathrm{T}_{1}\right)$ delay the flowering and maturity. In INM sources $\mathrm{T}_{6}$ took minimum days to flowering and maturity followed by $\mathrm{T}_{7}, \mathrm{~T}_{10}, \mathrm{~T}_{11}, \mathrm{~T}_{8}$, and $\mathrm{T}_{9}$ and maximum by $\mathrm{T}_{1}$ (control).

It was concluded from the result of experiment that integrated nutrient supply improved the growth, and development of rice. Substitution of $50 \% \mathrm{~N}$ through FYM+ $50 \% \mathrm{RDF}$ to rice accompanied with $100 \%$ RDF to wheat was better than $\mathrm{N}$ substitution through crop residue and green manuring as well as chemical treatments.

\section{References}

Anonymous (2015), Agriculture statistics at a glance 2015, Directorate of Economics and Statistics, Department of Agriculture and Cooperation, Ministry of Agriculture, government of India: 6971

Mahajan, A. and Gupta, R.D. (2009). The rice- wheat cropping system, integrated nutrient management (INM) in a sustainable rice-wheat cropping system, Springer Science, 109 -112.

Ladha, J.K., D. Dawe, H. Pathak, A.T. Padre, R.L. Yadav, Bijay-Singh, Yadvinder Singh, Y. Singh, P. Singh, A.L. Kundu, R. Sakal, N. Ram,A.P. Regmi, S.K. Gami, A.L. Bhandari, R. Amin, C.R. Yadav, S. Bhattarai, S. Das, H.P. Aggarwal, R.K. Gupta, and P.R. Hobbs.(2003). How extensive are yield declines in long-term rice-wheat experiments in Asia? Field Crops Res. 81:159-180

Yadav, R.L. Dwivedi B.S. Prasad, K. Tomar O.K. Shurpali N.J. and Pandey P.S. (2000) Yield trends, and changes in soil organic-C and available NPK in a longterm rice-wheat system under integrated use of manures and fertilisers Field Crops Research 68 (2000) 219-246.

Dwivedi, B. S. Shukla, A. K. Singh, V. K. and Yadv, R.L. (2001). Development of farmers' resource-based integrated plant nutrient supply systems: experience of a FAO-ICAR-IFFCO collaborative project and AICRP on soil test crop response correlation. Bhopal: Indian Institute of Soil Science. pp. 50-75

Mehdi, S. M. Sarfraj, M. Abbas*, S. T. Shabbir, G. and Akhtar, J. (2011): Integrated nutrient management for rice-wheat cropping system in a recently reclaimed soil. Soil Environ. 30(1): 36-44.

Mehta, S. (2004). Effect of integrated nutrient 
supply on growth and yield of wheat (Triticum aestivum). Annals of Agricultural Research 25(2): 289-291.

Saha, U.K., Islam, M.S. and Saha, R.R. (1998). Yield performance and soil nutrient balance under integrated fertilization in rice-wheat cropping system in a calcareous food plain soil of Bangladesh. Japanese Journal of Tropical Agriculture 42(1): 7-17.

\section{How to cite this article:}

Shobhit Singh, J.S. Bohra, Y.V. Singh, Amit Kumar Upadhyay, Shiv Shanker Verma, Pankaj Kumar Mishra and Raghuveer, M. 2017. Effect of Integrated Nutrient Management on Growth and Development Stages of Rice under Rice -Wheat Ecosystem. Int.J.Curr.Microbiol.App.Sci. 6(7): 2032-2042. doi: https://doi.org/10.20546/ijcmas.2017.607.241 